University of Nebraska - Lincoln

DigitalCommons@University of Nebraska - Lincoln

USDA Wildlife Services - Staff Publications

U.S. Department of Agriculture: Animal and Plant Health Inspection Service

2015

\title{
Food Habits of Adult Male White-Tailed Deer Determined by Camera Collars
}

\author{
Michael J. Lavelle \\ USDA/APHIS/WS National Wildlife Research Center, michael.j.lavelle@aphis.usda.gov \\ Chad R. Blass \\ United States Department of Agriculture, Animal and Plant Health Inspection Service, Wildlife Services, \\ National Wildlife Research Center, Fort Collins, CO \\ Justin W. Fischer \\ USDA/APHIS/WS National Wildlife Research Center, Justin.w.fischer@aphis.usda.gov
}

Scott E. Hygnstrom

University of Wisconsin-Stevens Point, shygnstrom1@unl.edu

David G. Hewitt

Texas A\&M University, david.hewitt@tamuk.edu

See next page for additional authors

Follow this and additional works at: https://digitalcommons.unl.edu/icwdm_usdanwrc

Part of the Life Sciences Commons

Lavelle, Michael J.; Blass, Chad R.; Fischer, Justin W.; Hygnstrom, Scott E.; Hewitt, David G.; and VerCauteren, Kurt C., "Food Habits of Adult Male White-Tailed Deer Determined by Camera Collars" (2015). USDA Wildlife Services - Staff Publications. 1799.

https://digitalcommons.unl.edu/icwdm_usdanwrc/1799

This Article is brought to you for free and open access by the U.S. Department of Agriculture: Animal and Plant Health Inspection Service at DigitalCommons@University of Nebraska - Lincoln. It has been accepted for inclusion in USDA Wildlife Services - Staff Publications by an authorized administrator of DigitalCommons@University of Nebraska - Lincoln. 
Authors

Michael J. Lavelle, Chad R. Blass, Justin W. Fischer, Scott E. Hygnstrom, David G. Hewitt, and Kurt C. VerCauteren 


\title{
Food Habits of Adult Male White-Tailed Deer Determined by Camera Collars
}

\author{
MICHAEL J. LAVELLE, ${ }^{\mathbf{1}}$ United States Department of Agriculture, Animal and Plant Health Inspection Service, Wildlife Services, \\ National Wildlife Research Center, 4101 LaPorte Avenue, Fort Collins, CO 80521, USA \\ CHAD R. BLASS, United States Department of Agriculture, Animal and Plant Health Inspection Service, Wildlife Services, \\ National Wildlife Research Center, 4101 LaPorte Avenue, Fort Collins, CO 80521, USA \\ JUSTIN W. FISCHER, United States Department of Agriculture, Animal and Plant Health Inspection Service, Wildife Services, \\ National Wildlife Research Center, 4101 LaPorte Avenue, Fort Collins, CO 80521, USA \\ SCOTT E. HYGNSTROM, College of Natural Resources, University of Wisconsin-Stevens Point, Stevens Point, WI 54481, USA \\ DAVID G. HEWITT, Caesar Kleberg Wildlife Research Institute, Texas AङM University, Kingsville, TX 78363-8202, USA \\ KURT C. VerCAUTEREN, United States Department of Agriculture, Animal and Plant Health Inspection Service, Wildife Services, \\ National Wildlife Research Center, 4101 LaPorte Avenue, Fort Collins, CO 80521, USA
}

\begin{abstract}
Many factors influence what and why animals select the foods they eat. Several methods have been used to estimate food habits of herbivores, but they all have limitations such as defining available foods and misrepresenting particular forages. We evaluated plant consumption by adult male white-tailed deer (Odocoileus virginianus) with camera collars in a semi-enclosed population in southern Texas, USA, during late autumn 2010. We collected 1,241 videos taken at all times of the day and night from 15 camera collars and confirmed consumption of 40 plant species with an $84 \%$ probability of identification. Diets of individual deer varied considerably, though there was an apparent preference for prickly-pear cactus (Opuntia engelmannii) and blackbrush acacia (Vachellia rigidula). Our results were consistent with other conventional studies of food habits of deer in the region. Yet, we feel camera collars provide a more thorough and detailed representation of forage species available and consumed. Strategic deployments of camera collars could advance the understanding of nutritional requirements and behavior of deer because a broad array of concurrent data can be collected. Published 2015. This article is a U.S. Government work and is in the public domain in the USA.
\end{abstract}

KEY WORDS camera, feeding habits, food selection, Odocoileus virginianus, white-tailed deer.

White-tailed deer (Odocoileus virginianus) are the most abundant and wide-ranging species of deer in North America (Hefflinger 2011). In Texas (USA) alone, the economic benefit of deer hunting exceeds US $\$ 2$ billion annually (Meek et al. 2008), emphasizing the species importance in land-use planning and management. Although flexible in diet, white-tailed deer typically select high-quality forage (Murden and Risenhoover 1993, Dostaler et al. 2011). The quality of forage available impacts the health and performance of the associated deer population; thus, a comprehensive knowledge of local plants and those preferred by deer is essential for managing habitat for deer (Hewitt 2011). Habitat improvements, such as food plots, canopy reduction, prescribed burns, fertilization, aeration, and timber or shrub removal are used to manipulate forage and increase productivity of deer (Stewart et al. 2000, Rogers et al. 2004, Ruthven and Krakauer 2004).

Received: 14 November 2014; Accepted: 9 March 2015 Published: 24 July 2015

${ }^{1}$ E-mail: michael.j.lavelle@aphis.usda.gov
Methods used to collect data on food habits of deer vary considerably in quality of data collected (i.e., potential for bias) and level of effort required (Sanders et al. 1980, Holechek et al. 1982, Dostaler et al. 2011, Baamrane et al. 2012). Analyses of rumen and fecal contents are common methods for assessing diets of deer, but are time-consuming and produce biased results because of variable levels of digestibility of forages (Ramirez et al. 1997, Dostaler et al. 2011, Hewitt 2011). Direct observations of captive-raised deer also are used to evaluate food habits of deer, but data may be biased by unnatural behaviors of habituated animals (McMahan 1964, Bryant et al. 1979, Holechek et al. 1982, Murden and Risenhoover 1993). Another source of error lies in identification and quantification of plants consumed during observations (Holechek et al. 1982). Utilization techniques and stem-count indices occasionally are used to quantify relative palatability and assess preference for species of browse, but are limited to plants that are not entirely consumed and occur within the area surveyed (Holechek et al. 1982, Rutledge et al. 2008).

Recently, researchers used animal-borne cameras to collect information from an animal's point of view (Beringer 
et al. 2004, Marshall et al. 2007, Lavelle et al. 2012, Thompson et al. 2012). Collection of potentially unbiased species-specific data on food habits may now be possible by using cameras, suggesting the advent of a novel tool for collecting data (Thompson et al. 2012). Our goal in this study was to demonstrate the utility of camera collars for collecting data on food habits of deer by examining fine-scale variation in forage species and frequency of consumption, as well as characterizing more broad-scale consumption of forage across time and space.

\section{STUDY AREA}

We evaluated camera collars on a 405 -ha property managed for deer and partially enclosed by a $2.5 \mathrm{~m}$ woven-wire fence near Zapata, Texas within Zapata County, USA $\left(26^{\circ} 90^{\prime} \mathrm{N}\right.$, $\left.99^{\circ} 26^{\prime} \mathrm{W}\right)$ in the South Texas Plains region. The climate of the region is generally mild with a growing season of 340360 days. Average annual temperatures ranges from $19^{\circ}$ to $23^{\circ} \mathrm{C}$ and rainfall averages $43 \mathrm{~cm}$ annually (Taylor et al. 1999). The property consists of xeric uplands and lacustrine areas bordering a large reservoir. Overstory vegetation included honey mesquite (Prosopis glandulosa), huisache (Vachellia farnesiana farnesiana), spiny hackberry (Celtis pallida), cenizo (Leucophyllum frutescens), creosotebush (Larrea tridentata), blackbrush (Vachellia rigidula), guajillo (Senegalia berlandieri), and guayacan (Guaiacum angustifolium). The property was managed to increase numbers and body condition of white-tailed deer by creating openings for primary-successional-stage plant species, restricting deer harvest, and providing supplemental feed corn.

\section{METHODS}

We used helicopter net-gunning to capture (Webb et al. 2008) adult male white-tailed deer. Deer were equipped with camera collars and ear tags, and photographed before being released. We deployed camera collars simultaneously in late November 2010 during the beginning of the rutting period for white-tailed deer in the region (Hellickson et al. 2008). We mounted production-model trail cameras (119435C, Trophy Cam ${ }^{\mathrm{TM}}$; Bushnell ${ }^{\mathbb{B}}$ Outdoor Products, Overland Park, KS) on Global Positioning System (GPS) collars (TGW-4500; Telonics, Inc., Mesa, AZ; see also Lavelle et al. 2012) equipped with programmed collar-release mechanisms (CR-2a; Telonics, Inc.) to facilitate camera retrieval at the conclusion of the study. Attempts to obtain GPS locations were scheduled every $15 \mathrm{~min}$ for the duration of the study. Cameras were activated by a passive infrared motion sensor that could be set at low, medium, and high settings depending on desired sensitivity and ambient temperatures. The passive infrared motion sensor had a range of $13.7 \mathrm{~m}$, with a trigger speed of $<1 \mathrm{~s}$ (manufacturerstated specifications). Video was captured in full color during daylight and black and white at night with the aid of 32 infrared light-emitting diodes.

The camera collars weighed $1.5 \mathrm{~kg}$, or approximately $2 \%$ of body mass, based on average weights of adult male whitetailed deer in the region (Hellickson et al. 2008). An earlier assessment on animal stress due to wearing camera collars demonstrated no difference in fecal glucocorticoid metabolite levels between deer outfitted with and without collars (Moll et al. 2009). We visually observed 3 of the cameracollar-equipped deer the evening after they were captured and released. We observed no abnormal behavior among these deer, and analyses of use areas over the next 2 weeks revealed no abnormal movements or behaviors. All procedures were approved by the Institutional Animal Care and Use Committee of the U.S. Department of Agriculture-Animal and Plant Health Inspection ServiceWildlife Services-National Wildlife Research Center (USDA-APHIS-WS-NWRC, QA-1591).

We programmed cameras to capture a $30 \mathrm{~s}$ video $(720 \times 480$ pixels/frame at 30 frames/sec) when motion was detected at the medium setting, with a time lag of $5 \mathrm{~min}$ before the camera could be triggered again. Cameras stored video data internally and were downloaded to a computer hard drive upon recovery. We viewed digital video clips on desktop computer monitors to extract data relative to plant species consumed. We enlisted the assistance of a Rangeland Sciences Specialist from the University of Texas A\&MKingsville with a high degree of expertise in identifying regional plant species to review videos and identify plants consumed.

To ensure a detailed and representative portrayal of consumption was collected for each individual, we omitted all data from cameras that lacked video of decipherable consumption or $\leq 30$ consumption events. We determined a deer was feeding only when the deer was observed taking a bite of a plant (Fig. 1). When unable to identify a plant to
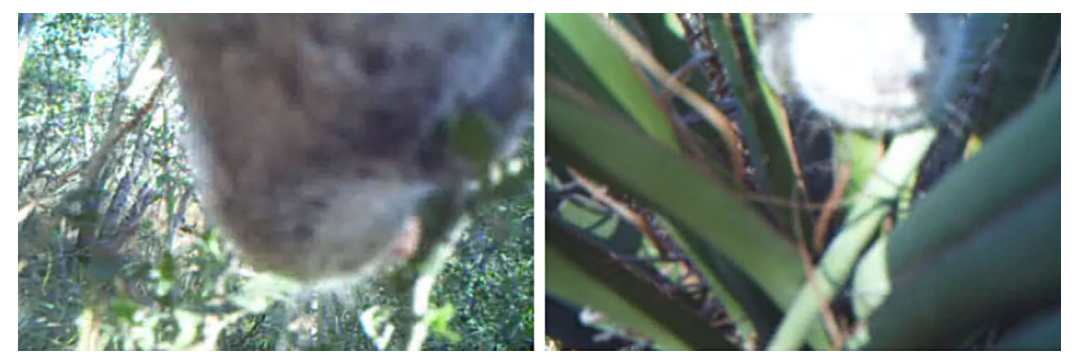

Figure 1. Images taken from camera collars used to collect consumption data from adult male white-tailed deer (Odocoileus virginianus) during autumn 2010 near Zapata, Texas, USA, including spiny hackberry (Celtis pallida, left) and Spanish dagger (Yucca treculeana, right). Note the ventral anterior portion of the lower mandible in the upper half of each image. 
species, we categorized the plant into broad forage-class designations: supplement, cactus, grass, forb, browse, and other (i.e., soil, sticks, fallen leaves). We recorded the occurrence of each species consumed on video and present descriptive statistics as well as the percentage composition of diet for each deer.

To characterize consumption more broadly, we observed and recorded the surrounding cover types on video: 1) grassland-herbaceous, 2) shrub-scrub, 3) developed-open, and 4) woody wetlands for each consumption event. We also used the National Land Cover Database (NLCD; Fry et al. 2011) in combination with deer GPS location data to classify land-cover type occupied using the same cover types mentioned above. To document a consumption event that occurred within a particular NLCD classified land-cover type, we only used consumption events that occurred within \pm 1 min of a GPS location. For these post hoc pairwise comparisons, we used a $\chi^{2}$ goodness-of-fit test to determine whether forage classes were being consumed equally within each land-cover type. A Bonferroni correction was applied because of multiple $\chi^{2}$ tests. We also provide a brief comparison of NLCD to our land-cover classifications to determine whether different methods for determining land cover could lead to differing results.

Lastly, we evaluated consumption temporally by categorizing a calendar day into four $6 \mathrm{hr}$ periods (0401-1000, 1601-2200, 1001-1600, and 2201-0400) representing the crepuscular, midday, and midnight periods, respectively; and we used the timestamp from each video consumption event. To determine whether a forage class was being consumed equally across, as well as within, all time periods, we used a $\chi^{2}$ goodness-of-fit test. Again, a Bonferroni correction was applied to account for multiple tests. For more general comparisons, we included forage composition estimates from previous research.

\section{RESULTS}

We captured, collared, and released 26 adult male whitetailed deer between 0800 and $1200 \mathrm{hr}$ on 29 November 2010. Seventeen cameras recorded clear video over an average of 7.3 days $(\mathrm{SD}=2.6)$ and 15 recorded $\geq 30$ videos/deer $(\bar{x}=77.6$, $\mathrm{SD}=30.4)$ in which consumption was visible and thus were included for further analysis. We identified 40 plant species from 1,039 of 1,241 consumption events (see Supporting Information online detailing species-specific consumption by deer), resulting in an $84 \%$ probability of identification. The 5 most frequently documented species consumed, contributing to $86.8 \%$ of all consumption, included prickly-pear cactus (Opuntia engelmannii; 40.5\%), blackbrush acacia (20.6\%), whole-kernel corn (Zea mays; 10.39\%) supplied as a supplement, buffelgrass (Cenchrus ciliaris; 10.30\%), and purple nutsedge (Cyperus rotundus; 5.00\%).

All 15 deer included in this evaluation were documented consuming at least a proportion of browse, cactus, and grass, with averages of $28 \%(\mathrm{SD}=15.9), 39 \%(\mathrm{SD}=16.6)$, and $19 \%(\mathrm{SD}=11.9)$, respectively (Fig. 2). Composition of species consumed varied by individual, with some individuals consuming $\geq 38 \%$ supplement (deer 4 and 12), $65 \%$ cactus (deer 11 ), $>30 \%$ grass (deer 6,9 , and 14 ), and $65 \%$ browse (deer 10). All deer consumed some browse, cactus, and grass, but some did not consume supplement (deer 1, 7, 8, and 13).

Comparisons of forage-class consumption based on cover types occupied recorded by camera and GPS resulted in variable results. Consumption of forage classes by cover type

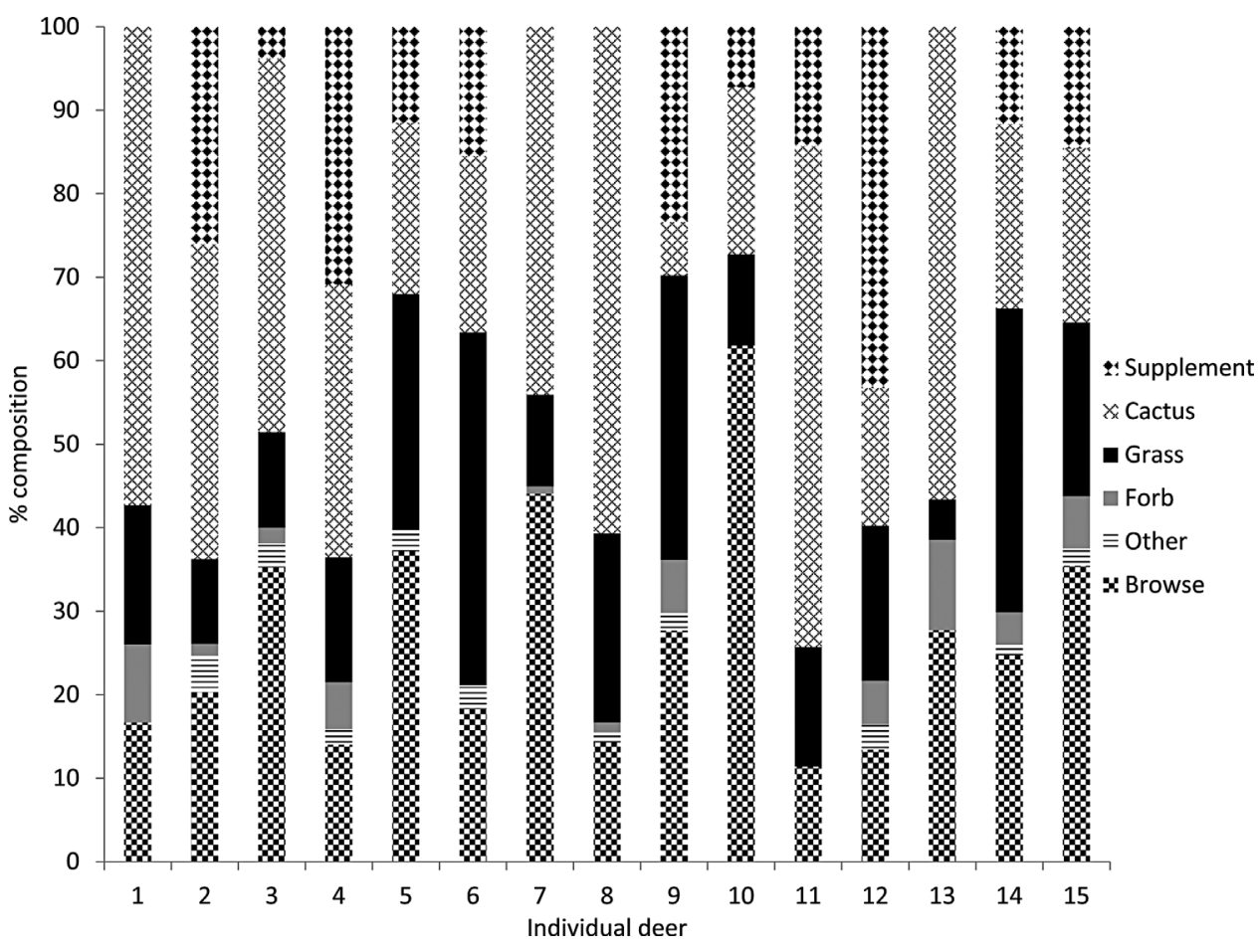

Figure 2. Forage composition (\%) of adult male white-tailed deer (Odocoileus virginianus) diets, collected with camera collars during autumn 2010 near Zapata, Texas, USA. 
occupied derived from observations ( $n=1,241$ events) revealed the highest consumption of browse in shrub-scrub (47.1\%, $\left.\chi^{2}=498.48, P<0.001\right)$, supplement in developedopen $\left(77.1 \%, \chi^{2}=181.28, P<0.001\right)$, cactus in grasslandherbaceous $\left(61.7 \%, \chi^{2}=343.55, P<0.001\right)$, and grass in woody wetlands $\left(59.9 \%, \chi^{2}=271.65, P<0.001\right.$; Fig. 3). Similar, but not identical, patterns of forage class consumption were observed when using the GPS data to classify cover type occupied, although our data were limited to 179 consumption events that occurred within \pm 1 min of a GPS fix. Consumption of cactus was highest, but not significant, in developed-open (75\%, $\left.\chi^{2}=8.50, P=0.075\right)$ cover type. Conversely, significantly higher consumption was documented with cactus in shrub-scrub $\left(34.62 \%, \chi^{2}=28.15\right.$,
$P<0.001)$, cactus in grassland-herbaceous $(45.98 \%$, $\left.\chi^{2}=58.00, P<0.001\right)$, and grass in woody wetlands (80\%, $\chi^{2}=27.11, P<0.001$; Fig. 3). Our comparison of observation- and GPS-derived cover types occupied during consumption events revealed several discrepancies. Observation-derived cover types of shrub-scrub were found to be occurring in all 4 cover types classified by NLCD, and grassland-herbaceous was found to occur in 3 NLCD cover types (all but woody wetlands).

We also found temporal variation in daily consumption of food items (Fig. 4). All forage classes, except for forbs $\left(\chi^{2}=1.51, P=0.68\right)$ were found to differ significantly between the 4 time periods (browse $\chi^{2}=15.61, P=0.001$; grass $\chi^{2}=21.23, P<0.001$, cactus $\chi^{2}=55.17, P<0.001$,

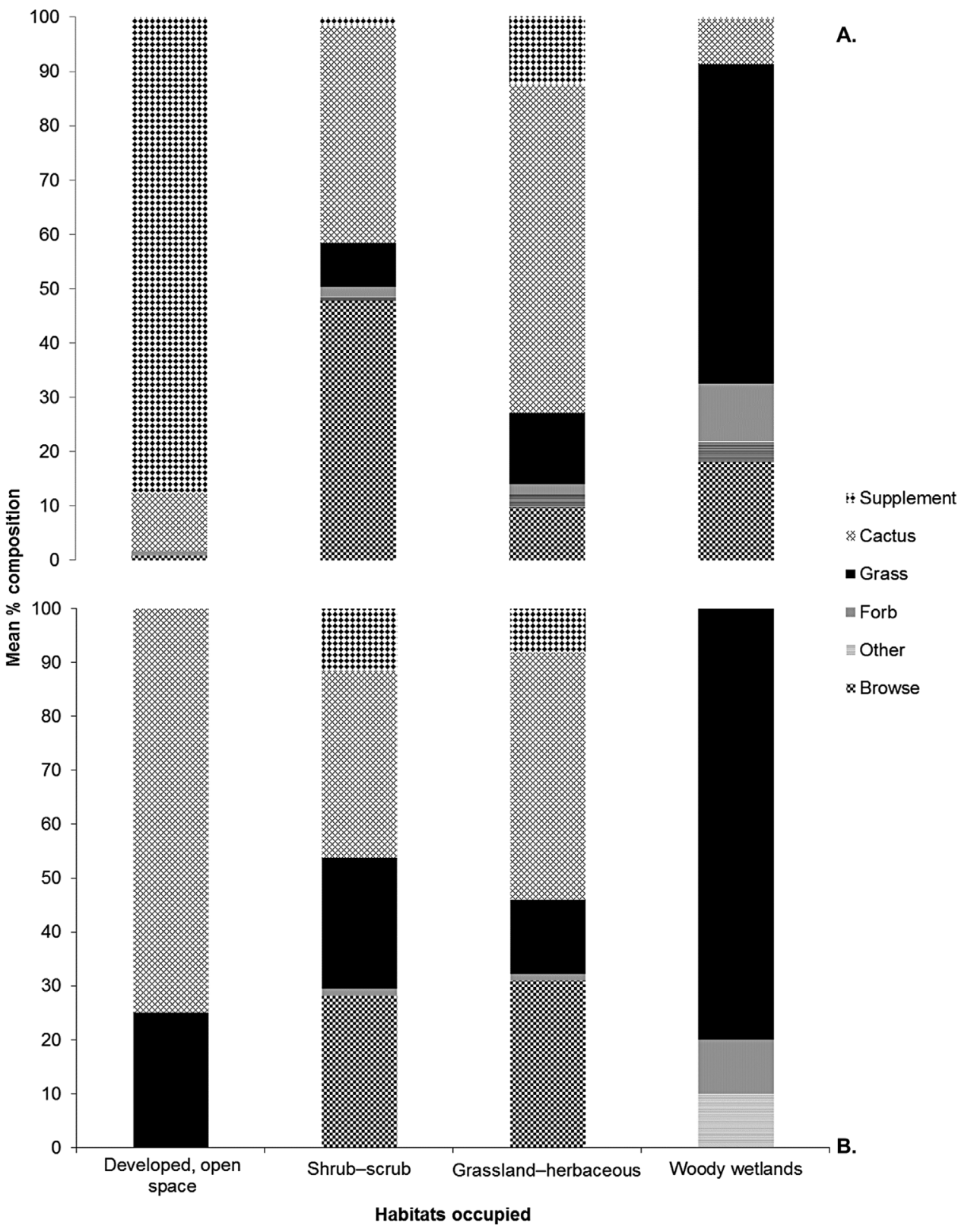

Figure 3. Forage composition (\%) of the diets of adult male white-tailed deer (Odocoileus virginianus) by cover type occupied, as determined through observation of surrounding cover types from video collected with camera collars (A) and as determined from Global Positioning System locations of deer during consumption events and corresponding National Land Cover Database cover types (B) during autumn 2010 near Zapata, Texas, USA. 


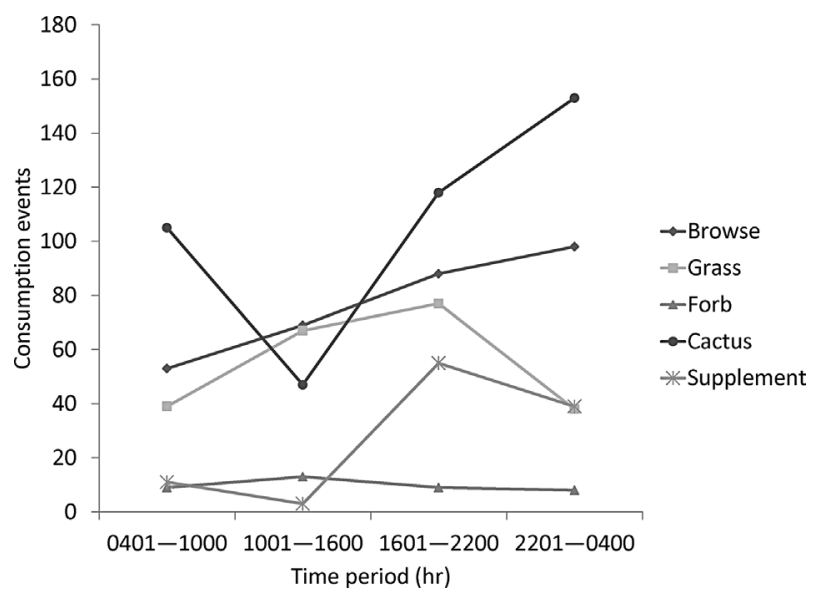

Figure 4. Total time-specific forage composition of adult male white-tailed deer (Odocoileus virginianus) across 4 daily time periods during autumn 2010 near Zapata, Texas, USA.

and supplement $\left.\chi^{2}=65.19, \quad P<0.001\right)$. Consumption events for browse and cactus were highest during 2201$0400 \mathrm{hr}$, and grass and supplemental corn were highest during $1601-2200 \mathrm{hr}$. There was also variability in the forage type consumed during time periods, with higher cactus consumption events during the $0401-1000 \mathrm{hr}\left(\chi^{2}=141.46\right.$, $P<0.001), 1601-2200 \mathrm{hr}\left(\chi^{2}=95.41, \quad P<0.001\right)$, and $2201-0400 \mathrm{hr}\left(\chi^{2}=200.34, P<0.001\right)$ time periods. Consumption did not occur equally across all forage types during the 1001-1600 $\mathrm{hr}$ time period $\left(\chi^{2}=200.34, P<0.001\right)$, with the majority of consumption events consisting of browse $(33.8 \%)$ and grass $(32.8 \%)$.

\section{DISCUSSION}

A variety of methods have been used to determine food habits of deer in southern Texas, including microscopic analysis of rumen content (Kie and Bower 1999), and using deer observations (Avey et al. 2003) and telemetry locations (Pollock et al. 1994) to draw inference on areas used by deer. Camera collars used in this study generated consumption data for diets of deer within southern Texas during autumn and winter that displayed variability similar to previous studies (Fig. 5; Everitt and Drawe 1974). Despite the variation in consumption of food items among individuals, we found significant consumption trends at the population level as well. For example, we found that deer consumed cactus during all time periods except late morning-early afternoon, when they primarily consumed browse. These consumption events were primarily in open, grassy areas, which would provide limited cover for deer during daylight hours. Consequently, deer may have avoided areas where cactus was present during the day in favor of areas that provide more cover for thermal relief and predator avoidance.

Forage availability affects selectivity of the diet of deer (Hewitt 2011) and without surveying a site when using other techniques such as fecal analysis, information on available plant species is missed. Camera collars facilitate evaluation of phenological stages of plants, furthering possibilities of determining seasonal preferences. In addition to plants consumed, information on plants available but not selected was also captured by video, allowing determination of preference for one species over another. Although we did not extract these data in our study, it would have been possible while reviewing video.

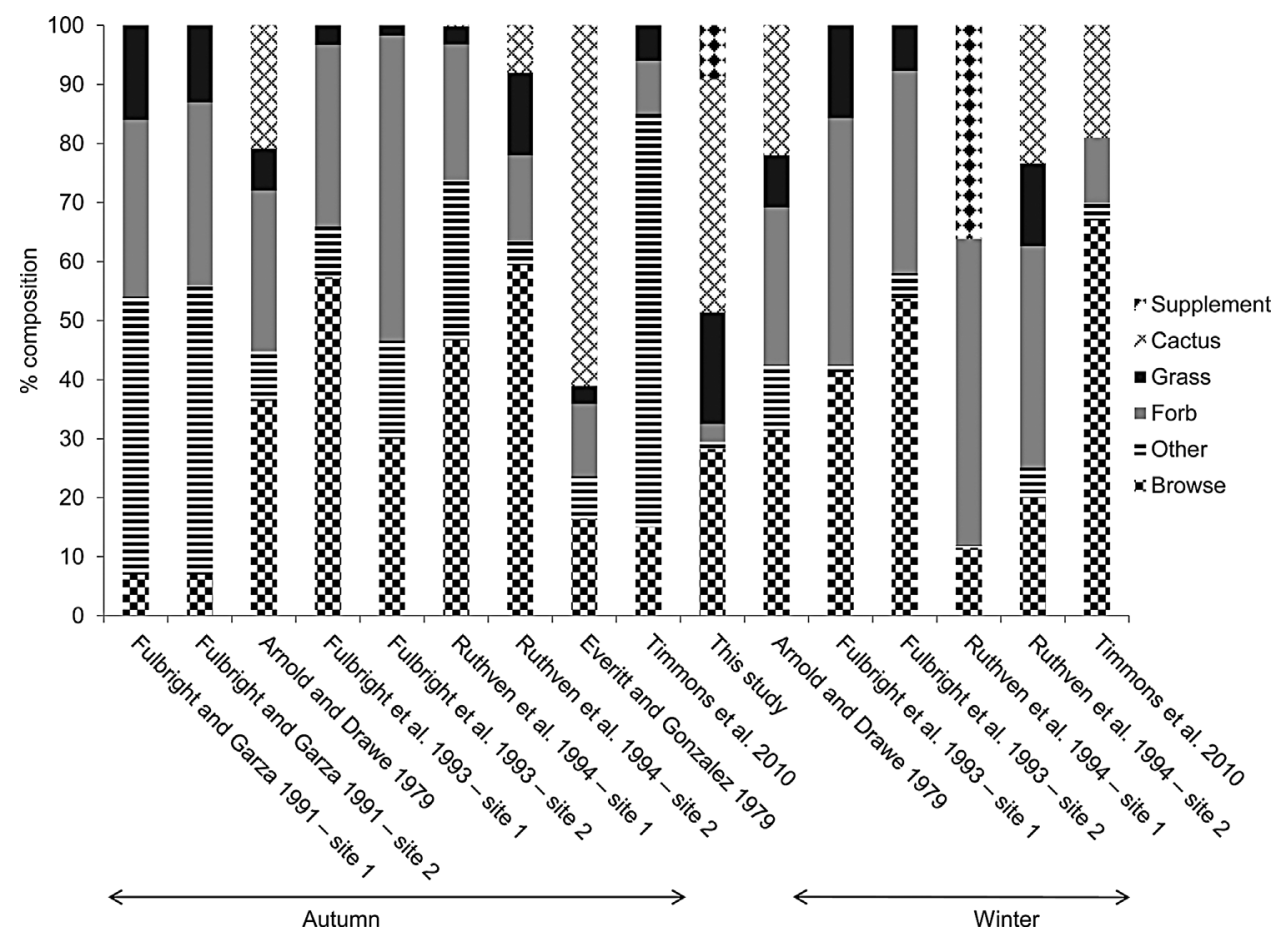

Figure 5. Seasonal and site-specific average estimates of forage composition (\%) of white-tailed deer (Odocoileus virginianus) diets from previous publications on food habits of deer in southern Texas, USA. 
Although quantity of vegetation consumed is not directly collected with video, volume and caloric intake could be assessed from vegetation components observed before and after consumption events. Amounts of forage eaten could be estimated rather than calculating a weighted average of consumption over a period of several days, as acquired from fecal and rumen analyses. When used in conjunction with other established techniques, camera collars provide a detailed picture of consumption, including feeding behavior, movement patterns within various cover types, bite frequency, bite size, forage selection, percent plant composition, and intra- and inter-species interactions while feeding. Further, while deploying camera collars, individual animals are handled, facilitating collection of individual-specific data pertaining to age, sex, morphology, body condition, and other parameters that contribute to the overall value of the consumption data collected.

By incorporating GPS receivers into our camera collars, we were also able to estimate location of foraging events, facilitating analysis of cover types occupied. Results describing cover type occupied during consumption extracted from GPS data as well as from video were generally similar, supporting the presumption that GPS collars are not essential for acquiring such data when camera collars are deployed. Further, inherent locational error associated with GPS devices, as well as spatial resolution of land-cover data, may produce misleading results and contribute to discrepancies between data collected from GPS versus camera collars. Although we refined our locational data to consumption events acquired within 1 min of GPS fixes, a deer can travel a considerable distance in $1 \mathrm{~min}$. This compounds the potential for misrepresenting locations within a particular cover type, especially when foraging may occur at small food patches, such as supplement provided in a feed site of $<4 \mathrm{~m}^{2}$. Conversely, video exhibits micro-cover types occupied concurrently during consumption. In conclusion, deer-borne cameras provide on-theground cover type, as close to 'truth' as we can get without intensive sampling of cover types.

Direct observations of foraging deer, combined with simultaneous surveys of available plant species, likely provide the most complete overall picture of food habits. When animals are observed foraging, however, it is difficult to identify and confirm forage consumed and presence of observers may alter behavior of foraging deer (McMahan 1964). Although observations and camera collars are the only means for collecting the complete picture of food habits beyond simply what is consumed they are both time-consuming methods. Fortunately camera collars can reliably collect information day or night despite adverse weather in dense vegetation where visibility is poor and in remote locations. The same is not always true with direct observations which can also be biased because of variability among observers. Our study was conducted with a semi-enclosed population of deer on managed habitat with supplemental feed; thus we potentially influenced results which may not be representative of deer in other scenarios.
Initial costs associated with camera collars may make them cost-prohibitive (US\$500-3000/unit; Lavelle et al. 2012). In addition, limited battery life is a current concern (Lavelle et al. 2012), yet acquisition of detailed and unbiased data may justify those costs and battery technology is improving. Production-model camera collars are currently being marketed and have been used for collecting data from free-ranging woodland caribou (Rangifer tarandus caribou; Thompson et al. 2012). Improvements in this relatively new technology likely will increase the cost-effectiveness and utility of this valuable tool. Although commonly used methods for determining food habits have been compared previously (Vavra et al. 1978, Smith and Shandruk 1979, McInnis et al. 1983), further comparisons with camera collars would be beneficial.

Traditional methods for exploring food habits of ruminants are limited, but methods are reasonably accurate and accepted, despite realized shortcomings. However, an array of additional information that has been missed or possibly misrepresented now is accessible with camera collars. We recommend consideration of camera collars when planning research directed at collecting a complete portrayal of food habits of deer and other animals. An array of consumptionrelated data is available from camera collars and is capable of providing an intimate understanding of what, when, and where deer are consuming forage. Considerable investments are made targeting management for white-tailed deer; therefore, it behooves managers and researchers to focus management based on a detailed understanding of preferences and behaviors of their white-tailed deer population. Camera collars facilitate access to this information and may also provide a means for evaluating the effects of management strategies to support current work or to direct future efforts.

\section{ACKNOWLEDGMENTS}

We thank C. Anderson, G. Clements, C. Currie, C. Ellis, L. Gulick, M. McCollum, C. Minor, R. Moll, P. Nol, R. Pleszewski, T. Ruby, J. Rhyan, G. Schuster, L. Soliz, G. Clements, and U.S. Department of Agriculture-Animal and Plant Health Inspection Service (USDA-APHIS)-Veterinary Services for assisting throughout the study. Special thanks to A. Hildreth for assisting with various aspects and responsibilities. We thank the Caesar Kleberg Wildlife Research Institute at Texas A\&M University-Kingsville for logistical support and the USDA-APHIS-Wildlife ServicesNational Wildlife Research Center for financial support. Editorial comments provided by T. Boal, C. Ribic, M. Hewison, N. Snow, and two anonymous reviewers improved this article and are greatly appreciated. Mention of companies or commercial products does not imply recommendation or endorsement by the USDA, nor does omission imply criticism. Product names are mentioned solely to report factually on available equipment and to provide specific information. There are no known conflicts of interest associated with this publication and there has been no significant financial support for this work influencing its outcome. 


\section{LITERATURE CITED}

Arnold, L. A., and D. L. Drawe. 1979. Seasonal food habits of white-tailed deer in the South Texas plains. Journal of Range Management 32:175178.

Avey, J. T., W. B. Ballard, M. C. Wallace, M. H. Humphrey, P. R. Krausman, F. Harwell, and E. B. Fish. 2003. Habitat relationships between sympatric mule deer and white-tailed deer in Texas. Southwestern Naturalist 48:644-653.

Baamrane, M. A. A., W. Shehzad, A. Ouhammou, A. Abbad, M. Naimi, E. Coissac, P. Taberlet, and M. Znari. 2012. Assessment of the food habits of the Moroccan dorcas gazelle in M'Sabih Talaa, West central Morocco, using the trnL approach. PloS ONE 7:e35643.

Beringer, J., J. J. Millspaugh, J. Sartwell, and R. Woeck. 2004. Real-time video recording of food selection by captive white-tailed deer. Wildlife Society Bulletin 32:648-654.

Bryant, F. C., M. M., Kothmann, and L. B. Merrill. 1979. Diets of sheep, angora goats, Spanish goats and white-tailed deer under excellent range conditions. Journal of Range Management 32:412-417.

Dostaler, S., J. P. Ouellet, J. F. Therrien, and S. D. Côté. 2011. Are feeding preferences of white-tailed deer related to plant constituents? Journal of Wildlife Management 75:913-918.

Everitt, J. H., and D. L. Drawe. 1974. Spring food habits of white-tailed deer in the South Texas plains. Journal of Range Management 27:15-20.

Everitt, J., and C. Gonzalez. 1979. Botanical composition and nutrient content of fall and early winter diets of white-tailed deer in South Texas. Southwestern Naturalist 24:297-310.

Fry, J. A., G. Xian, J. Suming, J. A. Dewitz, C. G. Homer, L. Yang, C. A. Barnes, N. D. Herold, and J. D. Wickham. 2011. Completion of the 2006 National Land Cover Database for the conterminous United States. Photogrammetic Engineering and Remote Sensing 77:858-864.

Fulbright, T. E., and A. Garza, Jr. 1991. Forage yield and white-tailed deer diets following live oak control. Journal of Range Management 44:451455.

Fulbright, T. E., J. P. Reynolds, and S. L. Beasom. 1993. Effects of browse rejuvenation on selected blood serum characteristics of white-tailed deer. Texas Journal of Agriculture and Natural Resources 6:41-48.

Hefflinger, J. 2011. Taxonomy, evolutionary history, and distribution. Pages 3-39 in D. G. Hewitt, editor. Biology and management of white-tailed deer. CRC, Boca Raton, Florida, USA.

Hellickson, M. W., T. A. Campbell, K. V. Miller, R. L. Marchington, and C. A. DeYoung. 2008. Seasonal ranges and site fidelity of adult male white-tailed deer (Odocoileus virginianus) in southern Texas. Southwestern Naturalist 53:1-8.

Hewitt, D. G. 2011. Nutrition. Pages 75-106 in D. G. Hewitt, editor. Biology and management of white-tailed deer. CRC, Boca Raton, Florida, USA.

Holechek, J. L., M. Vavra, and R. D. Pieper. 1982. Botanical composition determination of range herbivore diets: a review. Journal of Range Management 35:309-315.

Kie, J. G., and R. T. Bower. 1999. Sexual segregation in white-tailed deer: density-dependent changes in use of space, habitat selection, and dietary niche. Journal of Mammalogy 80:1004-1020.

Lavelle, M. J., S. E. Hygnstrom, A. M. Hildreth, T. A. Campbell, D. B. Long, D. G. Hewitt, J. Beringer, and K. C. VerCauteren. 2012. Utility of improvised video-camera collars for collecting contact data from whitetailed deer: possibilities in disease transmission studies. Wildlife Society Bulletin 36:828-834.

Marshall, G., M. Bakhtiari, M. Shepard, I. Tweedy, D. Rasch, K. Abernathy, B. Joliff, J. C. Carrier, and M. R. Heithaus. 2007. An advanced solid-state animal-borne video and environmental data-logging device (crittercam) for marine research. Marine Technology Society Journal 41:31-38.

McInnis, M. L., M. Vavra, and W. C. Krueger. 1983. A comparison of four methods used to determine the diets of large herbivores. Journal of Range Management 36:302-306.
McMahan, C. A. 1964. Comparative food habits of deer and three classes of livestock. Journal of Wildlife Management 28:798-808.

Meek, M., S. Cooper, M. Owens, R. Cooper, and A. Wappel. 2008. Whitetailed deer distribution in response to patch burning on rangeland. Journal of Arid Environments 72:2026-2033.

Moll, R. J., J. J. Millspaugh, J. Beringer, J. Sartwell, R. J. Woods, and K. C. VerCauteren. 2009. Physiological stress response of captive white-tailed deer to video collars. Journal of Wildlife Management 73:609-614.

Murden, S. B., and K. L. Risenhoover. 1993. Effects of habitat enrichment on patterns of diet selection. Ecological Applications 3:497-505.

Pollock, M. T., D. G. Whittaker, S. Demarais, and R. E. Zaiglin. 1994. Vegetation characteristics influencing site selection by male white-tailed deer in Texas. Journal of Range Management 47:235-239.

Ramirez, R. G., J. B. Quintanilla, and J. Aranda. 1997. White-tailed deer food habits in northeastern Mexico. Small Ruminant Research 25:141146.

Rogers, J. O., T. E. Fulbright, and D. C. Ruthven, III. 2004. Vegetation and deer response to mechanical shrub clearing and burning. Rangeland Ecology and Management 57:41-48.

Ruthven D. C., III, E. C. Hellgren, and S. L. Beasom. 1994. Effects of root plowing on white-tailed deer condition, population status, and diet. Journal of Wildlife Management 58:59-70.

Ruthven D. C., III, and K. L. Krakauer. 2004. Vegetation response of a mesquite-mixed brush community to aeration. Rangeland Ecology and Management 57:34-40.

Rutledge, J., T. Bartowskewitz, and A. Cain. 2008. Stem count index: a habitat appraisal method for South Texas. Texas Parks and Wildlife, Austin, USA.

Sanders, K. D., B. E. Dahl, and G. Scott. 1980. Bite-count vs fecal analysis for range animal diets. Journal of Range Management 33: 146-149.

Smith, A., and L. Shandruk. 1979. Comparison of fecal, rumen and utilization methods for ascertaining pronghorn diets. Journal of Range Management 32:275-279.

Stewart, K. M., T. E. Fulbright, and D. L. Drawe. 2000. White-tailed deer use of clearings relative to forage availability. Journal of Wildlife Management 64:733-741.

Taylor, R., J. Rutledge, and J. G. Herrera. 1999. A field guide to common south Texas shrubs. Texas Parks and Wildlife Press, Austin, USA.

Thompson, I. D., M. Bakhtiari, A. R. Rodgers, J. A. Baker, J. M. Fryxell, and E. Iwachewski. 2012. Application of a high-resolution animal-borne remote video camera with global positioning for wildlife study: observations on the secret lives of woodland caribou. Wildlife Society Bulletin 36:365-370.

Timmons, G. R., D. G. Hewitt, C. A. DeYoung, T. E. Fulbright, and D. A. Draeger. 2010. Does supplemental feed increase selective foraging in a browsing ungulate? Journal of Wildlife Management 74:995-1002.

Vavra, M., R. Rice, and R. Hansen. 1978. A comparison of esophageal fistula and fecal material to determine steer diets. Journal of Range Management 31:11-13.

Webb, S. L., J. S. Lewis, D. G. Hewitt, M. W. Hellickson, and F. C. Bryant. 2008. Assessing the helicopter and net gun as a capture technique for white-tailed deer. Journal of Wildlife Management 72:310-314.

Associate Editor: Hewison.

\section{SUPPORTING INFORMATION}

Additional supporting information may be found in the online version of this article at the publisher's web-site. The table details all plant species recorded by camera collars as being consumed by individual white-tailed deer (Odocoileus virginianus) during autumn 2010 near Zapata, Texas, USA. 